\title{
Contribution of knowledge leader and communication toward employee productivity at west Java conference office
}

\author{
Rolyana Ferinia \\ Doctoral Student at Universitas Pendidikan Indonesia, Bandung Indonesia \\ *Corresponding author E-mail: sibuearolyana@gmail.com
}

Copyright $\odot 2015$ Rolyana Ferinia. This is an open access article distributed under the Creative Commons Attribution License, which permits unrestricted use, distribution, and reproduction in any medium, provided the original work is properly cited.

\begin{abstract}
In any organization, knowledge leader and communication are subject which helps organizations reach productivity. The aim of the research is to study the contribution of knowledge leader and communication toward employee productivity at West Java Conference Office. To this end, this research used questionnaires distributed to 59 employees at West Java Conference Office. Data was calculated using Pearson Product Moment. All questionnaires are valid, and reliability using Cronbach's Alpha for knowledge leader was obtained at 0,846. Communication was obtained at 0,918 and productivity was obtained at 0,779 . Research method using descriptive analytical survey with quantitative data. Data was analyzed using Multiple Regression Analysis using T-Test. The result of the research shows that there is a significant influence on the knowledge leader toward productivity with significance (sig.) 0000 at the table with the value of $\alpha$ 0:05 coefficients it means $0.000<0.05$. There is a significant influence on communication toward productivity with significance (sig.) 0.035 at the table with the value of $\alpha 0,05$ it means $0.035<0.05$ and test of determination shows that the value of adjusted $\mathrm{R}$ Square is 0.873 , it indicates that the Knowledge Leader and Communication $87 \%$ effect on the productivity, and the remain of $13 \%$ is influenced by other variables, which is not examined yet.
\end{abstract}

Keywords: Knowledge Leader; Communication; Productivity.

\section{Introduction}

In an organization, leadership factors play an important role because the leader is a person who should mobilize and direct the organization in achieving organizational objectives. Leadership is an ability to influence others, in this case his subordinates in such a way so that other people willing to do the will of leaders personally though it may not please him. [1]. Interesting statement said that a manager did not have to be a Churchill or a heroic Lincoln, but a leader should have the ability and leadership skills to direct resources in organization to achieve the productivity of the company [2]. Drucker 1993 stressed that to the emergence of the new economy where knowledge is a resource that is not replaceable in order the organization able to survive, it needs also a leader who has a role as knowledge leadership [3]. Knowledge leaders are key to the establishment and encouragement of knowledge management in an organization. These people provide the vision, energy and enthusiasm to translate the knowledge concept into reality [4]. A knowledge leader should be able to help to build knowledge and translate vision into practice.

Concomitant to efforts a leader to exert his ability to mobilize his subordinates in order to increase organizational productivity, at the same time, a leader should have good communication about knowledge management to human resources that exist in the organization because a business activity cannot be separated from the communication process. Communication between employees and managers will be effective occurs when individuals reach a common understanding, stimulating the other party to act, and to encourage people to think in a new way. Ability to communicate effectively will increase productivity, both for you as well as business organizations [5]. 
Until recently, it has been a lot of studies and research on leadership effects on work productivity with leadership as independent variable and productivity as dependent variables, as well as research on the effects of communication with the leadership to with communication as independent variables and leadership as a dependent variable.

Several studies and research that may be relevant to the topic as research conducted by Vries, Pieper and Oostenveld entitled Leadership = Communication? The Relations of Leaders' Communication Styles with Leadership Styles, Knowledge Sharing and Leadership Outcomes showed that charismatic leadership style which is more human oriented, is more communicative, while the leadership style which is task-oriented are significantly less communicative, the strength of communication related to the knowledge sharing behavior [6]. In a study written by Soputan and Mogea of Leadership Effectiveness toward Service Productivity, the results indicate that there is a direct positive influence on the effectiveness of the service productivity leadership [7].

The studies above, in general, highlighting the leadership variables on productivity, not highlighting specific knowledge leader and organizational communication as a variable independent on the productivity of employees as dependent variables. Therefore, research on the influence of knowledge leader and communication of a leader (Conference Chair) on the productivity of the employees in the Office of West Java Conference become an interesting variable to study in order to know the actual conditions so that the development of productivity in the office can be done through a variety of leadership efforts.

\section{Literature review}

\subsection{Knowledge leader}

According to Storck and Hill [8] "knowledge leaders" are identified to whom members of the community turn when they have a particular knowledge need. Interaction, coordination and the dependence of the community from single members are weaker than in the case of a team. Knowledge leaders are key to the establishment and encouragement of knowledge management in an organization. These people provide the vision, energy and enthusiasm to translate the knowledge concept into reality [4]. Knowledge leader role and focus are determined by the organizational context, formalization of the knowledge focus, and the level of responsibility they hold. It means that effective knowledge leadership is central to the successful integration of a knowledge-center organization, an organization where knowledge management is a prime importance to the organization, and is reflected in the systems which operate.

A leader of knowledge (knowledge leader) has the generic attributes. There are some essential contributions knowledge leaders make that rely on an understanding system, processes and people, and shape them into a cohesive and functional whole. [1] Strategic visionary, [2] motivator, [3] communicator, [4] change agent, [5] coach, mentor and model, [6] learning facilitator [4].

\subsection{Communication}

Communication as the process by which a person, group, or organization (the sender) transmits some type of information (the message) to another person, group, or organization (the receiver) [9]. There are two major dimensions of managerial communication. It provides a framework for how managers communicate on a day-to-day basis and can be used as a point of departure for formally defining communication and the interpersonal processes of communication that is [1] a continuum ranging from humanistic interactor (who frequently interacts both up and down the organization system and exhibits human-oriented activities) to the mechanistic isolate (who communicates very little, except on a formal basis). [2] A continuum from the informal developer (who communicates spontaneously in all directions and exhibits activities related to developing his or her people) the formal controller (who uses formally scheduled communication interaction and exhibits monitoring/controlling activities [10].

\subsection{Productivity}

Labor productivity is a mental attitude [11]. Mental attitude that always looking for improvements to what was already exist. A belief that a person can do the job better today than yesterday, and tomorrow better than today. In the presence of work productivity will accomplish efficiency and effectiveness, and at the end will achieve the goals that have been set by the company. To measure the productivity of work, required an indicator, as follows [1] Training, [2] Mental and Physical Ability of Employees, [3] Relationship Between Top level/manager and Bottom level/employee [11].

\subsection{Theoretical frame work}

Knowledge Leader (X1): Independent Variable. Communication (X2): Independent Variable. Productivity (Y): Dependent Variable. 


\subsection{Hypothesis}

1) There is a significant contribution of the knowledge leader toward productivity at West Java Conference Office.

2) There is a significant contribution of Communication toward productivity at West Java Conference Office.

3) There are significant contribution of Knowledge leader and communication toward productivity at West Java Conference Office.

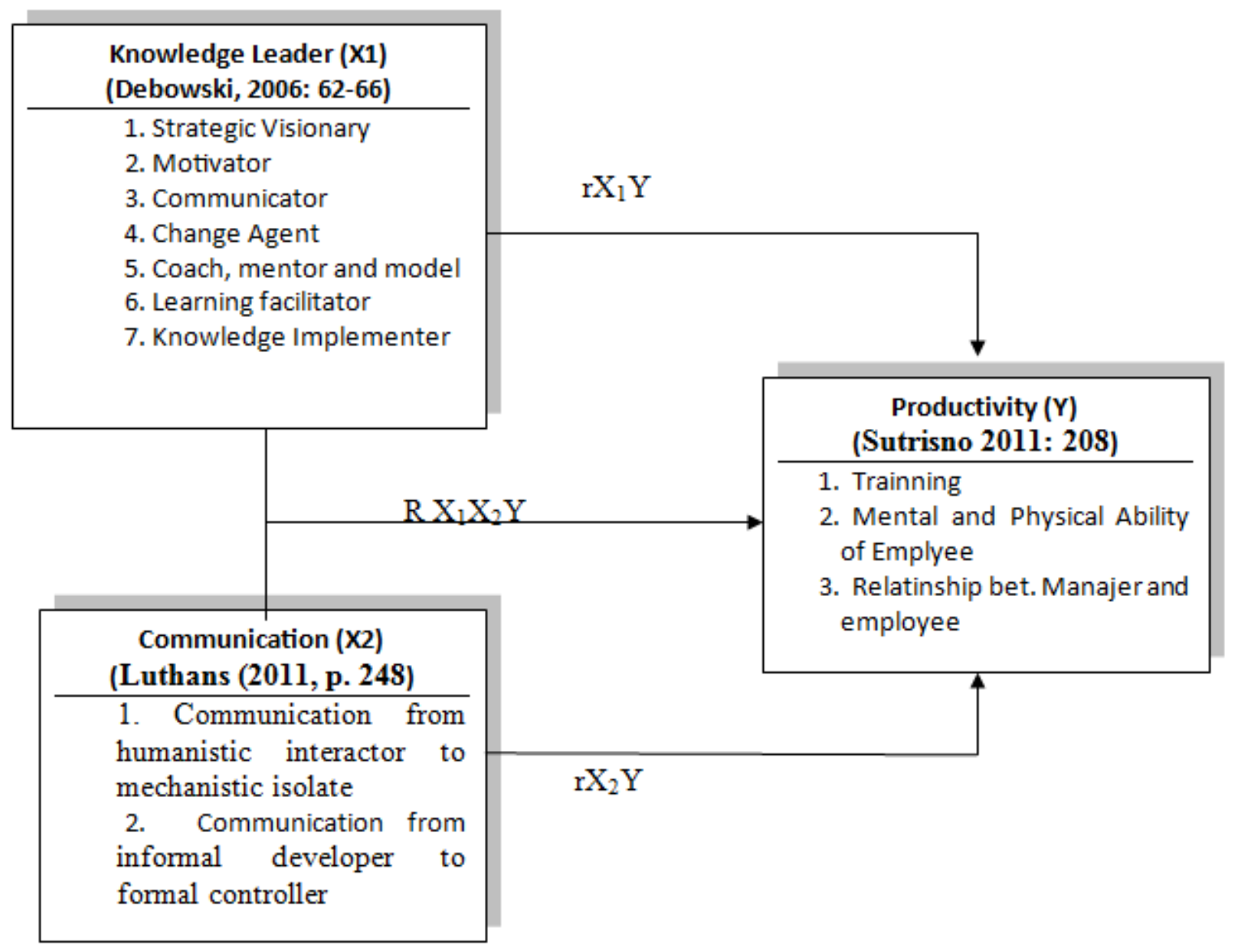

\section{Research methods}

The method used in this study is a descriptive analytic survey. Descriptive analytical method is an analytical survey seeks to describe and explain why a situation exist. Analytical survey studies of two or more variables in an attempt to answer the research question or examine the research hypothesis. Using quantitative data through multiple regression analysis using SPSS 16 [12]. Quantitative data if the data is the result of a series of observation or measurements are expressed in numbers [13] the object the studies were all the employees in the Office of Conference Java data collection technique using a questionnaire. Population are 59 employee working as pastor used as a sample.

\section{Results}

Characteristics of respondents viewed from age, education level and duration of work are described in Table 1.

Table 1: Characteristics of Respondent

\begin{tabular}{lll}
\hline Characteristic & Total & Percentage \\
\hline Age: & 3 & $3,4 \%$ \\
$24-35$ years old & 23 & $39,7 \%$ \\
$36-45$ years old & 27 & $46,6 \%$ \\
$46-55$ years old & 6 & $10,3 \%$ \\
55 years old & 59 & $100 \%$ \\
Total & & \\
Duration of work: & & \\
\hline
\end{tabular}




\begin{tabular}{lll}
\hline $1-5$ years & 5 & $8,6 \%$ \\
$6-10$ years & 12 & $20,7 \%$ \\
$11-15$ years & 16 & $27,6 \%$ \\
$16-20$ years & 18 & $31 \%$ \\
$21-25$ years & 3 & $5,2 \%$ \\
$26-30$ years & 5 & $6,9 \%$ \\
Total & 59 & $100 \%$ \\
Education: & & \\
Bachelor Degree & 35 & $59 \%$ \\
Master Degree & 24 & $41 \%$ \\
Total & 59 & $100 \%$ \\
\hline
\end{tabular}

\subsection{Validity and reliability}

Validation using Pearson Product Moment, as stated at Table 2, Reliability using Alpha Cronbach as stated at Table 3.

Table 2: Validity Test Results Variable Knowledge Leader, Communication and Productivity

\begin{tabular}{|c|c|c|c|}
\hline Item & r calculate & $\mathrm{r}$ table minimum $*$ ) & Valid rcal > r tab \\
\hline \multicolumn{4}{|c|}{ Knowledge Leader: } \\
\hline $\mathrm{X} 1$ & 0,677 & 0,300 & Valid \\
\hline $\mathrm{X} 2$ & 0,633 & 0,300 & Valid \\
\hline X3 & 0,542 & 0,300 & Valid \\
\hline $\mathrm{X} 4$ & 0,686 & 0,300 & Valid \\
\hline X5 & 0,606 & 0,300 & Valid \\
\hline X6 & 0,359 & 0,300 & Valid \\
\hline$X 7$ & 0,676 & 0,300 & Valid \\
\hline $\mathrm{X} 8$ & 0,486 & 0,300 & Valid \\
\hline X9 & 0,382 & 0,300 & Valid \\
\hline $\mathrm{X} 10$ & 0,511 & 0,300 & Valid \\
\hline $\mathrm{X} 11$ & 0,563 & 0,300 & Valid \\
\hline $\mathrm{X} 12$ & 0,535 & 0,300 & Valid \\
\hline $\mathrm{X} 13$ & 0,633 & 0,300 & Valid \\
\hline $\mathrm{X} 14$ & 0,668 & 0,300 & Valid \\
\hline $\mathrm{X} 15$ & 0,356 & 0,300 & Valid \\
\hline $\mathrm{X} 16$ & 0,414 & 0,300 & Valid \\
\hline $\mathrm{X} 17$ & 0,404 & 0,300 & Valid \\
\hline \multicolumn{4}{|c|}{ Communication: } \\
\hline $\mathrm{X} 18$ & 0,491 & 0,300 & Valid \\
\hline X19 & 0,491 & 0,300 & Valid \\
\hline $\mathrm{x} 20$ & 0,416 & 0,300 & Valid \\
\hline $\mathrm{x} 21$ & 0,491 & 0,300 & Valid \\
\hline \multicolumn{4}{|c|}{ Productivity: } \\
\hline y1 & 0,674 & 0,300 & Valid \\
\hline y2 & 0,615 & 0,300 & Valid \\
\hline y3 & 0,665 & 0,300 & Valid \\
\hline y4 & 0,767 & 0,300 & Valid \\
\hline y5 & 0,610 & 0,300 & Valid \\
\hline y6 & 0,444 & 0,300 & Valid \\
\hline y7 & 0,727 & 0,300 & Valid \\
\hline y8 & 0,475 & 0,300 & Valid \\
\hline y9 & 0,414 & 0,300 & Valid \\
\hline
\end{tabular}

Table 3: Reliability Test Results Variable Knowledge Leader, Communication and Productivity

\begin{tabular}{llll}
\hline Variable & $\mathrm{R}$ & Cronbach & Decision \\
\hline & & Alpha & Reliable \\
Knowledge Leader & 0,846 & 0.6 & Reliable \\
Communication & 0,918 & 0.6 & Reliable \\
Productivity & 0,779 & 0.6 & \\
\hline
\end{tabular}




\subsection{Classical assumption test}

1) Normality Test

Dependent Variable: Produktivitas

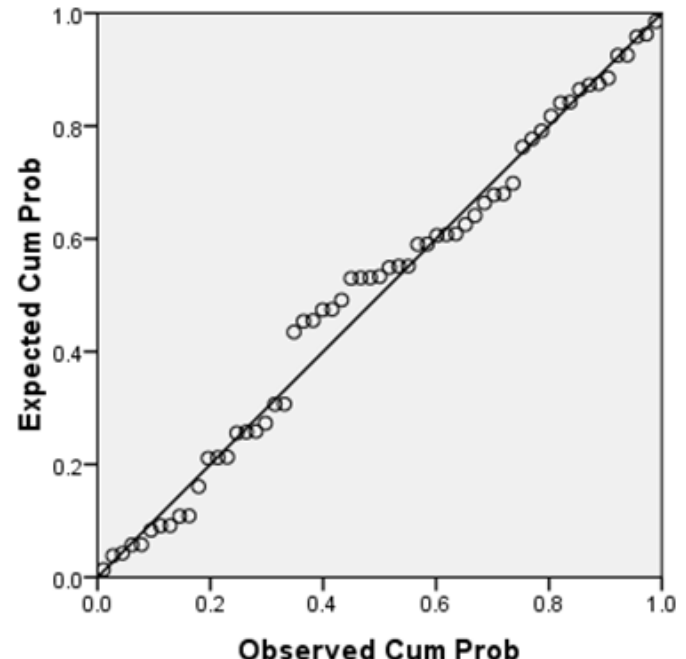

Fig. 1: Normal P-P Plot of regression standardized Residual

The above picture confirms that the regression model obtained normal distribution, where the distribution of the data are at about the diagonal line.

2) Assumptions Multicolinearity Test

Table 4: Result Test: Asumsi Multicolinearity Assumtion Knowledge Leader
\begin{tabular}{|c|c|}
\hline $\mathrm{R}=0.936$ & $\mathrm{R}$ Square $=0.876$ \\
\hline Data processed by SPSS v. 16 &
\end{tabular}

From the output of the above can be seen that high R Square is 0.876 , indicating a greater value of $\alpha$ of 0.05 , the overall VIF value is $14.66 \%$ above $10 \%$ showed no symptoms of multicollinearity as stated at table 4 .

Table 5: Result Test: Asumsi Multicolinearity Assumtion Communication

\begin{tabular}{|c|c|}
\hline $\mathrm{R}=0.302$ & $\mathrm{R}$ Square $=0.091$ \\
\hline Data processed by SPSS v. 16 &
\end{tabular}

From the above output can be viewed R Square of 0.091 indicates a greater value than $0.05 \alpha$, overall VIF value is $39.65 \%$ above $10 \%$ showed no symptoms of multicollinearity as stated at table 5 .

3) heteroscedasticity Test

\section{Dependent Variable: Produktivitas}

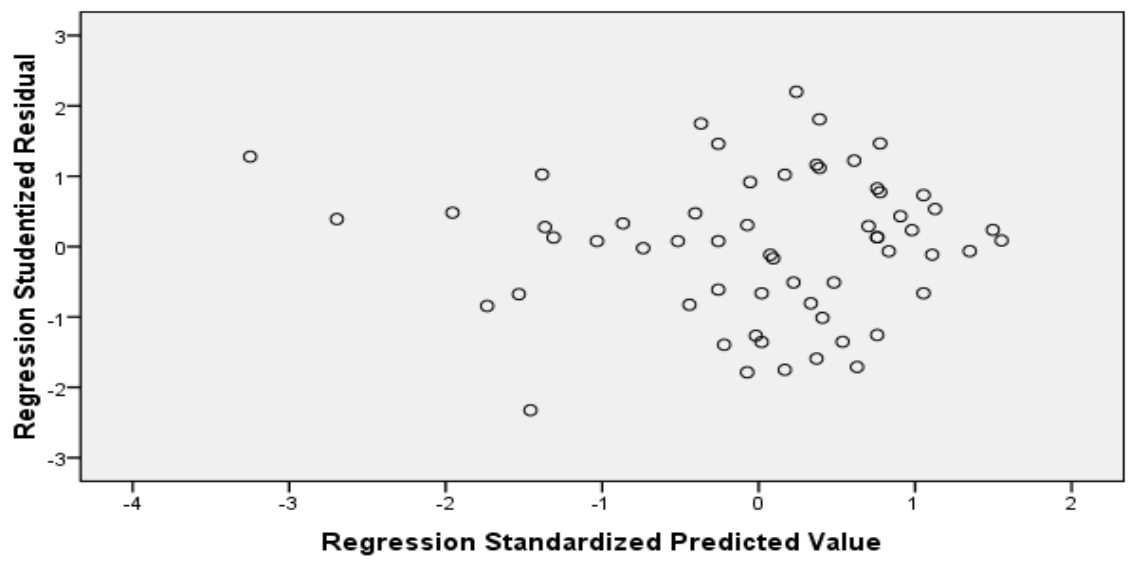

Fig. 2: Heteroscedasticity Test 
Seen from the picture above, that scatter plot does not from a clear pattern, and the points spread above and below 0 on the axis Y. So it can be concluded that occur heteroscedasticity regression model. Then use the data that we have qualified for the regression.

Multiple Regression Analysis

Table 6: T-Test

\begin{tabular}{|l|l|l|l|l|}
\hline Model & $\mathrm{B}$ & $\mathrm{t}$ & Sig. & Adjusted R Square \\
\hline (Constant) & -1.850 & -.866 & .390 & \\
\hline Knowledge Leader & .571 & 18.974 & .000 & .874 \\
\hline Communication & -.071 & -.924 & .359 & .862 \\
\hline $\begin{array}{l}\text { Dependent Variable: } \\
\text { Productivity }\end{array}$ & $\mathrm{R}=.937$, Adjuste \\
$\mathrm{R}$ Square 0.873 & & \\
\hline
\end{tabular}

From Table 6 the estimated multiple linear regression models are:

$\mathrm{Y}=-1.850+0.571 \mathrm{X} 1-0.071 \mathrm{X} 2$

The effect of Knowledge Leader toward Productivity shows from adjusted R Square is 0.874 and the effect of Communication toward Productivity shows from adjusted R Square is 0,862. The effect of Knowledge Leader and Communication toward Productivity shows from adjusted R Square is 0.873 , it indicates that the Knowledge Leader and Communication $87 \%$ effect on the productivity, and the remain of $13 \%$ is influenced by other variables, which are not examined yet.

\section{Conclusions and suggestions}

\subsection{Conclusions}

1) Contribution of Knowledge Leader (X1) toward Productivity (Y), Knowledge Leader has a significance (sig.) 0000 at the table with the value of $\alpha$ 0:05 coefficients it means $0.000<0.05$ or there is a significant influence on Knowledge Leader toward Productivity.

2) Contribution of Communication (X2) toward Productivity (Y), Communication has a significance (sig.) 0.035 at the table with the value of $\alpha 0,05$ it means $0.035<0.05$ or there is a significant influence on the Communication toward Productivity.

3) Test of determination shows that the value of adjusted R Square is 0.873, it indicates that the Knowledge Leader and Communication $87 \%$ effect on the productivity, and the remain of $13 \%$ is influenced by other variables, which are not examined yet.

\subsection{Suggestions}

From the results of the analysis showed that the Knowledge and Communication in the organization has a significant impact toward Productivity. These findings suggest that a leader who has the knowledge of the visionary strategy, motivator, communicator, change agent, coach, mentor, a model and as a facilitator of learning will be able to affect the productivity in the organization.

Furthermore, the findings of this study also showed that the better the communication in organization will affect productivity significantly. Thus, these findings support the theory that is with the efforts of a leader to exert his ability to move his subordinates in order to increase organizational productivity at the same time a leader must also be able to communicate well about knowledge of human-resource management to the existing in the organization as a business activity cannot be separated from the communication process.

In practical, these findings explain that the Chairman of the Conference of West Java in this case as a knowledge leader with visionary strategies, and also as a motivator, communicator, agent of change, trainer, mentor, and as a facilitator of learning models still need to make improvements to the enhancement of leadership in order productivity of workers will get better through training, mental and physical attitude and the relationship between superiors and subordinates. Communication between the Chairman of the Conference of West Java to colleagues also, still need to be improved so that the productivity of their employees work better.

This research is still very limited because of its scope only in one organization, so the results cannot be generalized to other areas, in the future, the researchers plan to conduct research on organizational broader scope covering Central Java, East Java, Kalimantan and Sumatra (Organization scattered throughout Indonesia, in the two major regions, namely the Western Region which includes Jakarta, West Java, East Java, Central Java, Borneo, Sumatra, and the Eastern Region of Indonesia which includes Manado, Ambon, Kupang, Irian), so the result will be more accurate and provides a thorough overview. 


\section{References}

[1] Romli, Komunikasi Organisasi, Jakarta: Kompas Gramedia, P92, 2011

[2] Sopiah, Perilaku Organisasional, Yogyakarta,Andi Offset,p108,2008.

[3] Sarabia, Maria. 2007. Knowledge leadership cycles: an approach from Nonaka's viewpoint. Journal of Knowledge Management, Vol. 11, No. 3, pp. 6-15. http://dx.doi.org/10.1108/13673270710752072.

[4] Debowski, Shelda,Knowledge Management, Australia, John Wiley \& Sons,p58,62-65.2006

[5] Wahdi, Mohamad,Komunikasi Bisnis, Jakarta, PT Buku Seru,p1,2011.

[6] De Vries, E. B, Reinout, P, Angeique, W, Oostenveld. 2010. Leadership Communication? The Relations of Leaders' Communication Styles with Leadership Styles, Knowledge Sharing and Leadership Outcomes. Journal Business Psychology, 25, 367-380. http://dx.doi.org/10.1007/s10869-009-9140-2.

[7] Soputan, Grace Jenny dan Mogeab, Tini. 2012. Leadeship Effectiveness toward Service Productivity, An International Journal of Sciences: Basic and Applied Research. Vol. 13 no. 1.

[8] Maier, Ronald, Knowledge Management Systems, 3rd edition, New York, Springer, p88, 2007.

[9] Greenberg, Jerald, Behavior in Organization, 10th edition, England, Pearson Education Limited, p323, 2011.

[10] Luthans, Fred, Organizational Behvior, 12th edition, Singapore,Mc- Graw Hill,p248,2011.

[11] Sutrisna, Edy,Budaya Organisasi,Jakarta,Kencana Prenada Media Group, p100,2011.

[12] Morissan,Metode Penelitian Survey,Jakarta'Kencana,p166,2014.

[13] Silalahi, Ulber,Metode Penelitian Sosial, Bandung,Refika,p282,2012. 